\title{
Políticas Públicas de Desenvolvimento Rural no Brasil: o dilema entre inclusão produtiva e assistência social.
}

\author{
Ademir Antonio Cazella ${ }^{2}$ \\ Adinor José Capellesso ${ }^{3}$ \\ Monique Medeiros ${ }^{4}$ \\ Andréia Tecchio ${ }^{5}$ \\ Yannick Sencébét \\ Fábio Luiz Búrigo ${ }^{7}$
}

\section{Resumo}

Nas duas últimas décadas, estabeleceu-se uma evidente dicotomia entre as políticas de caráter produtivo e aquelas destinadas à assistência social das unidades agrícolas familiares no Brasil. Este artigo tem por objetivo analisar esse processo de dualização das principais políticas públicas destinadas à agricultura familiar, elaborando um panorama quantitativo dos seus resultados. Do ponto de vista metodológico, a análise se apoia sobre o número de agricultores beneficiados pelas políticas de reforma agrária, crédito rural, mercados institucionais de alimentos, previdência social rural e transferência de renda. Os principais resultados deste estudo indicam que o apoio econômico para as atividades produtivas da agricultura familiar brasileira tem se concentrado nas camadas intermediárias e consolidadas inseridas nos mercados. Em paralelo, a maior parte dos agricultores familiares é relegada ao assistencialismo social, não integrando as agendas de trabaIho das principais organizações profissionais agrícolas.

Palavras-chave: Agricultura familiar; inclusão socioprodutiva; não recurso.

I Os autores agradecem ao apoio da Fundação de Amparo à Pesquisa e Inovação do Estado de Santa Catarina (FAPESC) durante a realização desse trabalho.

2 Professor permanente do Programa de Pós-graduação em Agroecossistemas da Universidade Federal de Santa Catarina (PGA/UFSC). E-mail: ademir.cazella@ufsc.br.

3 Professor do Instituto Federal de Educação, Ciência e Tecnologia de Santa Catarina, doutorando PGA/UFSCe Bolsista FUMDES. E-mail: adinor.capellesso@ifsc.edu.br.

4 Doutoranda do PGA/UFSC e bolsista CAPES. E-mail: mmedeiros@ymail.com.

5 Doutoranda da Universidade Federal Rural do Rio de Janeiro (CPDA/UFRRJ) e bolsista CAPES. E-mail: deiatecchio@yahoo.com.br.

6 Professora do Agrosup Dijon - França. E-mail: yannick.sencebe@dijon.inra.fr.

7 Professor colaborador do Programa de Pós-graduação em Sociologia Política da UFSC e Professor permanente do PGA/UFSC. E-mail: fabio.burigo@ufsc.br. 


\section{Introdução}

A partir da metade dos anos de 1990, o Estado brasileiro iniciou a elaboração de um conjunto de políticas públicas direcionadas à agricultura familiar. Esse processo foi associado à mobilização de organizaçóes sociais ruraiseao acúmulo de estudos técnicos e científicos, que demonstraram a importância socioeconômica desse segmento social. A engenharia institucional para viabilizar o apoio do Estado às unidades agrícolas familiares, aliada às pressóes sociais pela reforma agrária e por políticas específicas para a agricultura familiar, explica o fato de o Brasil ter sido um dos raros países a ter dois ministérios dedicados à gestão de políticas públicas de desenvolvimento rural e agrícola. De um lado, o Ministério da Agricultura, Pecuária e Abastecimento (MAPA), órgão tradicionalmente voltadoao mercado de commodities e às agroindústrias de grande porte e, de outro, o Ministério do Desenvolvimento Agrário (MDA), criado em 1999 para coordenar as políticas fundiárias eapoiar a agricultura familiar ${ }^{8}$. Essa categoria social foi reconhecida legalmente somente em $2006^{9}$, momento em que se já contava com políticas públicas específicas de diversas naturezas orientadas à produçáo de alimentos para os mercados internos, ao acesso a terra, ao desenvolvimento territorial em zonas rurais, previdência rural, entre outras.

Desde o seu surgimento na década de 1990, as iniciativas públicas de desenvolvimento rural sofreram importantes transformaçóes. Tais mudanças podem ser compartimentalizadas em três geraçóes de políticas, embora as ações do Estado nesse domínio não seguiram uma linearidade temporal, já que se intercruzaram ao longo do tempo (GRISA; SCHNEIDER, 2015). A primeira geração, associada a demandas de segmentos sociais da agricultura familiar organizados em sindicatos e movimentos sociais, está ligada principalmente a

8 Em maio de 2016, com o afastamento de Dilma Rousseff, o Presidente Michel Temer promoveu uma reforma administrativa. Nessa reforma, o MDA foi extinto. Algumas de suas funções foram transferidas à Secretaria Especial de Agricultura Familiar e do Desenvolvimento Agrário, vinculada à Casa Civil, e outras para um novo ministério, que passou a se dominar Ministério de Desenvolvimento Social e Agrário.

9 A Lei da Agricultura Familiar, n I1.326, entrou em vigor em julho de 2006 e definiu os seguintes critérios para que um estabelecimento agropecuário seja considerado familiar: área de até quatro módulos fiscais, mão de obra predominantemente familiar, renda gerada na sua maior parte pelas atividades agropecuárias e gerenciamento do estabelecimento efetuado pela própria família. Também são considerados como sendo agricultores familiares os silvicultores, os aquicultores, os extrativistas, os pescadores artesanais e os indigenas que praticam agricultura ou extrativismo (BRASIL, 2006). 
questôes agrícolas e agrárias. A segunda foi marcada pela criação e expansão de políticas de assistência social, ainda que o processo de reformulação da previdência rural - a principal açáo de Estado nessa área - teve início com a Constituição de 1988. E a terceira geração está relacionada à construção de novos mercados para os produtos e serviços oriundos da agricultura familiar, tendo como foco a segurança alimentar e a sustentabilidade.

Apesar detodas essas políticas públicas buscarem contemplar uma série de demandas oriundas de segmentos sociais enquadrados na categoria de agricultores familiares, as distintas açóes não foram suficientemente articuladas entre si, de modo a gerar um processo de transformação estrutural das unidades produtivas economicamente mais fragilizadas. Essas unidades representam a maior parte dos 4.367.902 estabelecimentos familiares recenseados pelo Instituto Brasileiro de Geografia e Estatística (IBGE) durante o último censo agropecuário, ocorrido em 2006 (INSTITUTO BRASILEIRO..., 2009). Na atualidade, percebe-se, de maneira geral, uma clara dicotomia entre as políticas de caráter produtivo e as destinadas à assistência social. As primeiras têm beneficiado, de forma prioritária, unidades familiares que utilizam tecnologias e práticas agronômicas convencionais destinadas a maximizar a produtividade, sem estabelecer contrapartidas concernentes aos impactos socioambientais. Ao inverso, as políticas que focalizam aassistência social dos estabelecimentos mais frágeis não têm interfaces com as iniciativas cujo foco é a inclusão produtiva. Em consequência disso, embora não se possa negar que tais políticas tenham influenciado na minimização da pobreza, mantêm-se no meio rural um número significativo de famílias pobres, muitas delas constituídas por pessoas idosas e sem perspectiva de melhorar a sua situação econômica. Essa dualização tem impactos negativos na capacidade de reprodução dessas unidades produtivas familiares, visto que os jovens rurais se sentem pouco estimulados a permanecer no campo e os idosos apresentam condiçóes limitadas para ampliar suas bases produtivas. Problemas como a idade avançada, o acesso precário a terra e a inexistência de herdeiros são, na maioria das vezes, compensados pelos auxílios financeiros oriundos de programas de assistência social.

Este artigo tem como objetivo discutir o processo de construçáo e de gestão das principais políticas públicas destinadas à agricultura familiar associado ao fenômeno dedualização, tendo por base os dados de acesso a essas políticas. Para tanto, selecionou-se cinco políticas públicas com o propósito 
de intercruzar as informaçóes relativas ao número de unidades produtivas ou de famílias beneficiadas. No grupo das políticas de caráter produtivo, o artigo analisou as seguintes iniciativas: as açóes de reforma agrária, o crédito agrícola subsidiado gerido pelo Programa Nacional de Fortalecimento da Agricultura familiar (Pronaf), e as compras públicas de alimentos (mercados institucionais) efetivadas por meio do Programa de Aquisição de Alimentos (PAA) e do Programa Nacional de Alimentação Escolar (PNAE). Já no grupo das políticas de caráter assistencial, o estudo priorizou o sistema de previdência social rural e a transferência de renda do Programa Bolsa Família (PBF).

Geralmente, as análises dessas políticas se dão de forma isolada, sem grandes esforços relativos à quantificação do número de famílias beneficiadas. Entretanto, uma abordagem conjunta dessas políticas pode fornecer elementos para promover a reorientação da concepção e da gestáo, no sentido de torná-las mais apropriadas à realidade política atual e aos desafios socioeconômicos que o Estado brasileiro deverá priorizar.

A hipótese defendida aqui é que, não obstante os avanços em termos de abrangência, os processos de construção e de gestão das principais políticas orientadas para a agricultura familiar sáo a expressáo dos interesses e da capacidade de mobilizaçáo de grupos socialmente mais articulados do ponto de vista político-organizacional. Isso tem favorecido grupos de produtores familiares considerados intermediários em termos de renda, além dos já plenamente inseridos nos mercados. Essa tendência não contempla a significativa diversidade social dessa categoria e reforça osdesafios técnicos e científicos de construção de políticas adaptadas a essa heterogeneidade ${ }^{10}$. Com base na análise realizada por Castel (2009), pode-se dizer que a implantação de políticas públicas no Brasil tem duas incoerências maiores. Primeiramente, elas revelam uma herança do Estado social centralizado e incapaz de considerar "[...] a heterogeneidade das situaçóes locaise da diversidade das trajetórias pessoais" (CASTEL, 2009, p. 42). Em segundo lugar, elas incorporamde forma ambígua a lógica da "contrapartida", que condiciona a concessão de um benefício a um esforço desprendido por parte do beneficiário. Enquanto essa lógica

10 A pesquisa coordenada por Lamarche (199I) foi uma das primeiras a destacar a diversidade interna da agricultura familiar, categoria que abrange famílias em situação socioeconômica como a de agricultores sem-terra até os agricultores organizados em sindicatos e cooperativas e integrados aos mercados. 
vem sendo aplicada a certas políticas assistenciais que beneficiam um grande número de pessoas pobres, o acesso a políticas de caráter produtivista, concernentes aos melhores integrados nos mercados, ocorre de forma automática e sem maiores restriçóes.

Segundo Castel (2009), a contrapartida pode assumir duas conotaçóes. A primeira, alvo de críticas do autor, se refere ao contexto neoliberal de fragilização dos direitos sociais confinados a um status de assistência que legitima o controle social, sempre exigindo mais (pagamento) daqueles que têm menos. Já a segunda, é entendida como uma medida de empoderamento do público em dificuldade, na medida em que as contrapartidas devem se destinar ao fortalecimento das capacidades dos assistidos. Nesses termos, a trajetória das políticas públicas orientadas à agricultura familiar brasileira ainda está longe de caminhar para aquilo que Castel chama de "um Estado social ativo", capaz de articular as lógicas dos direitos sociais ao empoderamento das pessoas por meio da descentralização e adaptação a situaçóes e percursos. $\mathrm{O}$ exemplo mais nítido nesse sentido diz respeito à correlaçáo entre sustentabilidade ambiental e a política de crédito rural subsidiado, já que praticamente inexistem contrapartidas ambientais dos beneficiários do Pronaf. Portanto, sem desconsiderar os avanços observados nos últimos anos em termos de construção de políticas de caráter assistencial e produtivo, o desafio consiste em integrá-las na perspectiva do desenvolvimento rural sustentável, gerando uma nova dinâmica nas esferas sociais, econômicos e ambientais.

Com intuito de aprofundar as discussóes acerca dessa problemática, o artigo está dividido em quatro partes principais, além desta introdução. As duas primeiras abordam o acesso dos agricultores familiares, respectivamente, às políticas produtivas, com ênfase na reforma agrária, no Pronaf e nos mercados institucionais, e às políticas assistenciais, tendo por base a previdência rural e o programa Bolsa Família. A terceira parte busca sintetizar os diferentes acessos dos agricultores familiares às distintas políticas públicas, destacando o profundo desconhecimento que se tem no país em relação às unidades produtivas que se desviam, por razóes diversas, do modelo de agricultura produtivista. $\mathrm{Na}$ quarta, efetua-se um esforço de comparação das políticas analisadas em termos de alcance social, evidenciando as consequências negativas que essa dualidade nas açóes do Estado gera em termos de desenvolvimento rural. Nas consideraçôes finais, é apresentada uma abordagem integrada das questóes 
debatidas nos tópicos anteriores. Destaca-se também a necessidade de estudos que inovem no sentido de compreender as estratégias de reprodução social de segmentos sociais da agricultura familiar que náo integram as agendas de trabalho das principais organizaçóes que atuam no meio rural.

\section{Políticas de natureza produtiva para a agricultura familiar}

A separação entre políticas produtivas e políticas assistenciais tem, sobretudo, um caráter analítico, pois a maioria das políticas produz sempre resultados, tanto de natureza econômica quanto social, de difícil separação. Todavia, os objetivos e resultados esperados dessas políticas tendem a estar mais relacionados a um ou a outro desses polos: econômico-produtivo ou social. Neste tópico, serão apresentados os números de unidades familiares beneficiadas pelas políticas de reforma agrária, Pronaf e PAA/PNAE. As abrangências dessas políticas serão comparadas com o universo de estabelecimentos agrícolas familiares levantados pelo Censo Agropecuário de 2006 que, apesar de antigo, é ainda abase de dados mais recente sobre a estrutura agrária brasileira. Trata-se, portanto, de um parâmetro de comparação que não reflete exatamente a realidade atual. $\mathrm{Na}$ última década, várias mudanças ocorreram no meio rural em termos produtivos e demográficos, mas não se tem nenhum indicativo de que ocorreram acentuadas variaçóes, para mais ou para menos, na quantidade de estabelecimentos. Nesse censo, do total de 5.175 .489 estabelecimentos agropecuários, $84,4 \%$ (4.367.902) foram classificados como familiares, sendo os demais (807.587) considerados não familiares (INSTITUTO BRASILEIRO..., 2007).

\section{I.I Reforma agrária: favelas rurais ou salvaguarda da agricultura} familiar?

Após duas décadas de Ditadura Militar (1964-1985), os anos 1980 foram marcados pela expressiva mobilizaçáo social e pelo processo de redemocratização do país. No meio rural, destacou-se a forte pressáo política exercida por segmentos da agricultura familiar, que reivindicavam do Estado um conjunto de direitos: reforma agrária, políticas de crédito agrícola, serviços públicos de extensão rural e a universalizaçáo da previdência social rural, entre outros. Embora alguns pontos dessa agenda tivessem ampla aceitaçáo setorial, a 
reforma agrária se chocava com interesses políticos do agronegócio, consolidadospor articulações que se ramificavam em vários órgãos do Governo Federal, em especial,no interior do Ministério da Agricultura, Pecuária e Abastecimento. Diante desse ambiente institucional desfavorável, foi necessário criar um ministério extraordinário para tratar da reforma agrária e de açóes correlatas, o qual passou por sucessivas reconfiguraçóes até dar origem,em 2000, ao Ministério do Desenvolvimento Agrário. Essa estrutura institucional, que funcionou até a saída da Presidente Dilma em 2016, coordenou as políticas públicas destinadas ao desenvolvimento rural e à agricultura familiar, incluindo as ações relacionadas às questôes fundiárias"

O reconhecimento político e a alocação de recursos públicos para a agricultura familiar não diminuíram a atenção dada pelo aparelho de Estado ao conjunto de políticas consideradas estratégicas para o crescimento do setor agropecuário. As açóes visando o fortalecimento do ambiente institucional e as dotaçóes orçamentárias, especialmente destinadas ao crédito rural subsidiado, priorizam amplamente as formas de produção não familiares. Os temas da reforma agrária e da agricultura familiar continuam ofuscados pela expressão político-econômica do agronegócio exportador, defendido com argumentos de eficiência produtiva e importância para os saldos positivos da balança comercial.

As políticas de reforma agrária são criticadas tanto pelos representantes do agronegócio quanto pelas lideranças sindicais e dos movimentos sociais. Os primeiros consideram as ações de reforma agrária ultrapassadas e responsáveis pela criação de favelas rurais. Já os segundos denunciam a morosidade dos governos e, sobretudo, a pequena abrangência das açóes, o que torna as medidas inócuas e incapazes de corrigir a elevada concentração de terras existente no país. Em que pese essas controvérsias, os resultados da reforma agrária náo podem ser negligenciados, uma vez que quase um terço da área ocupada pela agricultura familiar brasileira advémdessa política pública. As informaçóes da Tabela 1, a seguir, evidenciam a existência de 1.320.463 famílias assentadas em áreas de reforma agrária, com uma área média de aproximadamente 67 ha por família.

II O Instituto Nacional de Colonização e Reforma Agrária (Incra), órgão que desde a década de 1970 gerencia as ações de reforma agrária no Brasil, estava formalmente ligado ao MDA. Além disso, das quatro secretarias desse Ministério, duas eram específicas para coordenar outras políticas fundiárias - Secretaria de Reordenamento Agrário (SRA) e Secretaria Extraordinária de Regularização Fundiária da Amazônia Legal (Serfal). 
Tabela I: Famílias assentadas e área incorporada pelos programas de reforma agrária no Brasil até 2014

\begin{tabular}{|c|c|c|}
\hline Ano & $\begin{array}{c}\text { Famílias } \\
\text { assentadas }\end{array}$ & $\begin{array}{c}\text { Área } \\
\text { (hectares) }\end{array}$ \\
\hline Até 1994* & 58.317 & 16.290.069 \\
\hline 1995 & 42.912 & 2.683 .062 \\
\hline 1996 & 62.044 & 2.515 .865 \\
\hline 1997 & 81.944 & 4.165 .754 \\
\hline 1998 & 101.094 & 3.025 .000 \\
\hline 1999 & 85.226 & 2.303 .118 \\
\hline 2000 & 60.521 & 2.151 .574 \\
\hline 2001 & 63.477 & 1.829 .428 \\
\hline 2002 & 43.486 & 2.401 .925 \\
\hline Total Gov. F. H. Cardoso & 540.704 & 21.075 .726 \\
\hline 2003 & 36.301 & 4.526 .138 \\
\hline 2004 & 81.254 & 4.687 .393 \\
\hline 2005 & 127.506 & 13.437 .558 \\
\hline 2006 & 136.358 & 9.237 .949 \\
\hline 2007 & 67.535 & 5.747 .068 \\
\hline 2008 & 70.157 & 4.143 .246 \\
\hline 2009 & 55.498 & 4.633 .822 \\
\hline 2010 & 39.479 & 1.878 .008 \\
\hline Total Gov. Lula & 614.088 & 48.291 .182 \\
\hline 2011 & 22.021 & 1.902 .884 \\
\hline 2012 & 23.075 & 322.314 \\
\hline 2013 & 30.239 & 315.574 \\
\hline 2014 & 32.019 & 415.436 \\
\hline Total Gov. Dilma & 107.354 & 2.956.208 \\
\hline Soma Geral & 1.320 .463 & $88.613 .185^{* *}$ \\
\hline
\end{tabular}

*Parte dos dados corresponde ao periodo da Ditadura Militar, inexistindo informações disponiveis segundo os distintos governos; ${ }^{*} O$ somatório das áreas incorporadas em cada período apresenta uma diferença de 315.576 ha para mais, em relação ao total geral apresentado na base de dados do INCRA (88.928.76I ha). Os autores não conseguiram obter um esclarecimento sobre a discrepância junto ao INCRA. Fonte: INSTITUTO NACIONAL... (2015). 
Embora esses dados estatísticos suscitem questionamentos, a exemplo das críticas de movimentos sociais que acusam os distintos governos de superestimar o número de agricultores assentados por meio da inclusão de situaçóes de regularização fundiária - que gera o fornecimento de títulos de proprietários a agricultores posseiros -, a categoria sociopolítica de "agricultores assentados" se integrou na agenda das políticas públicas de desenvolvimento rural. A criação dos primeiros assentamentos está na origem das reivindicaçóes de uma política diferenciada de crédito rural subsidiado para a agricultura familiar.

\section{I.2 O Programa Nacional de Fortalecimento da Agricultura Familiar: crédito para o “agronegocinho”?}

A partir da década de 1930, a política agrícola brasileira privilegiou o financiamento das atividades produtivas por meio de créditos subsidiados de custeio e investimento agrícola. Dentre as justificativas, Delgado (1985) destaca a necessidade de viabilizar as oligarquias cafeeiras por meio da taxa de câmbio múltipla, criada para redirecionar recursos das exportaçóes de produtos agropecuários para apoiar a industrialização. Todavia, foi somente a partir de 1996, com a criação do Pronaf, que um número significativo de agricultores familiares passa a se beneficiar de empréstimos subsidiados pelo Estado para financiar os investimentos em suas unidades produtivas e as suas despesas operacionais (SCHNEIDER; MATTEI; CAZELLA, 2004). Esse programa tornou-se a principal política pública setorial para essa categoria social, constituindo-se como um "[...] arranjo de políticas com efeitos muito diferenciados segundo o público envolvido, o que parece ser um resultado previsível em face da heterogeneidade social que caracteriza a agricultura familiar" (NIEDERLE; FIALHO; CONTERATO, 2014, p. 16). Com a eleição de Luiz Inácio Lula da Silva (2003-2010) à Presidência da República, o montante de recursos do Pronaf aumentou de forma expressiva. Esse aumento não diminuiu as verbas concedidas pelo Governo ao financiamento da chamada agricultura empresarial, que permaneceu quase sempre seis vezes maior que o atribuído à agricultura familiar. O Gráfico 1, a seguir, ilustra os volumes de recursos previstos e executados pelos Planos Safra da Agricultura Familiar (PSAF) e os Planos Agrícolas e Pecuários (PAP) geridos, respectivamente, pelo MDA e pelo MAPA. 
Gráfico I: Montantes de recursos de crédito rural disponibilizados e executados por meio do PSAF e do PAP- em valores deflacionados(2002-2015)

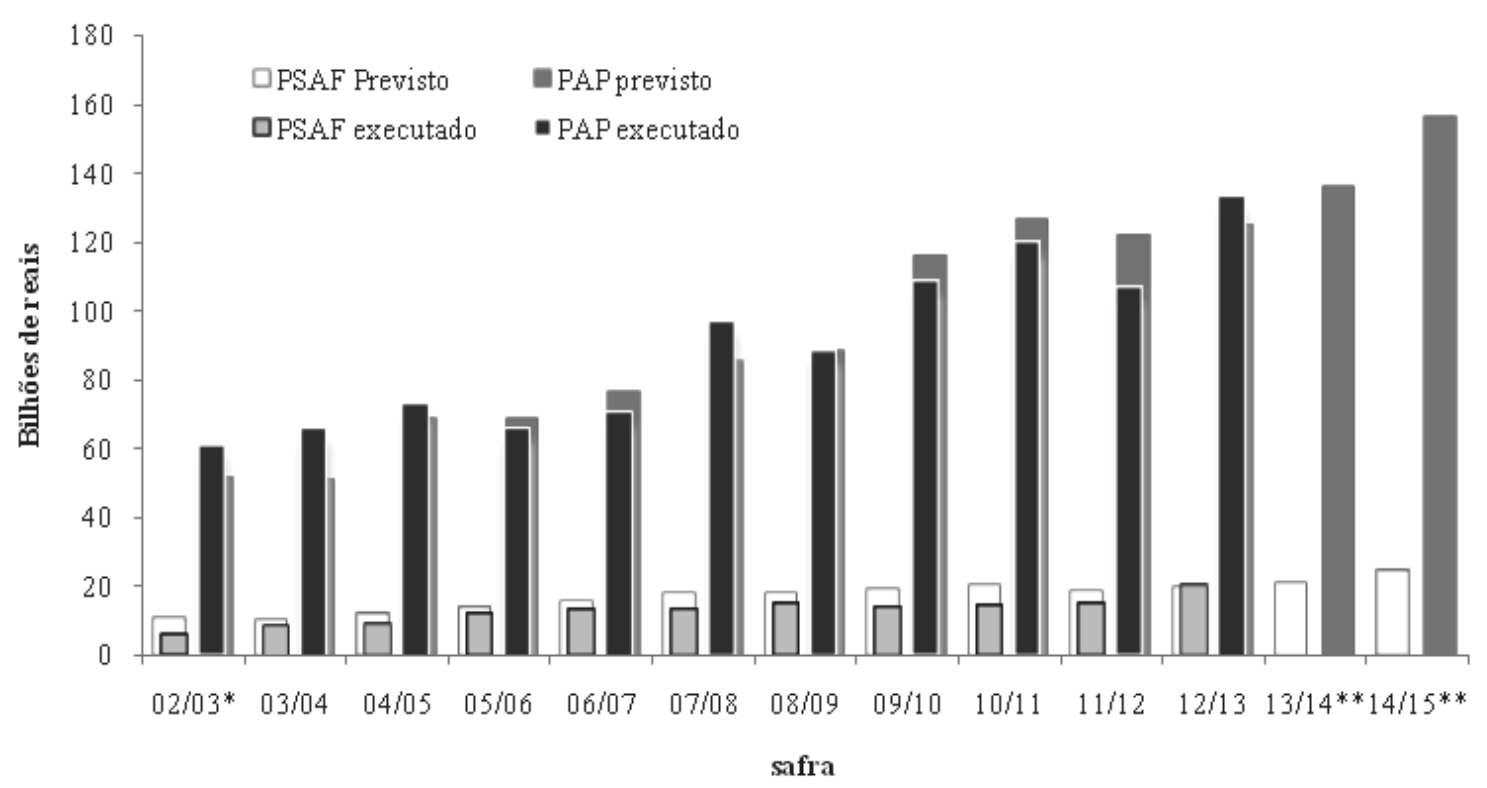

Obs.: Os valores foram deflacionados pelo IGP-DI tendo 2013 com base 100. * Último ano do Gouerno Fernando Henrique Cardoso; ${ }^{* *}$ Dados de execução não finalizados. Fonte: Planos Safra da Agricultura Familiar e Planos Agrícola e Pecuário;adaptadospelos autores.

Sabe-se que algumas linhas de crédito que dão sustentação às políticas do MAPA também acabam, direta ou indiretamente, beneficiando setores da agricultura familiar. Todavia, na maioria das vezes, esse apoio alcança agricultores familiares mais capitalizados, principalmente os que estáo inseridos em cadeias produtivas de alta densidade econômica, configurando esses casos mais como exceção do que em regra' ${ }^{12}$.

Não obstante a crescente diferença nos montantes destinados ao PSAF e ao PAP observa-se que os recursos destinados à agricultura familiar expandiram-se gradativamente após 2003. Os valores liberados no âmbito do

12 Podem-se citar nesse sentido os seguintes programas: Programa de Modernização à Irrigação e Cultivos Protegidos (Moderinfra), o Programa de Modernização da Frota de Tratores Agrícolas e Implementos Associados e Colheitadeiras (Moderfrota), o Programa ABC (Agricultura de Baixa Emissão de Carbono), os programas de investimento para construção de armazéns, inovação e modernização tecnológica na agropecuária (Inovagro e Moderagro), os destinados às cooperativas (Prodecoop e Procap-Agro) e o Programa Nacional de Apoio ao Médio Produtor (Pronamp). Além disso, existem outros recursos direcionados aos agricultores familiares, que não se constituem em empréstimos, vinculados aos programas de compras de estoques de alimentos, operados pela Companhia Nacional de Abastecimento (Conab/MAPA). 
Pronaf só ultrapassaram o teto disponibilizado no ano agrícola de 2012/2013, havendo sobras de recursos na maior parte dos anos. Ou seja, o valor total contratado pelos agricultores, por meio do Pronaf, náo foi limitado por falta de previsão orçamentária de subsídios governamentais ou por insuficiência de recursos disponíveis junto aos agentes do Sistema Financeiro Nacional que são responsáveis pela viabilização da política de crédito rural. Os resultados ficaram abaixo da meta principalmente por entraves associados à operacionalização dos contratos e à gestão dessa política no plano local.

Após duas décadas de Pronaf, verifica-se um consenso em muitas abordagens a respeito de seus resultados positivos e limitaçóes. As principais críticas ressaltam a persistente desigualdade observada na distribuição de recursos entre as cinco macrorregióes do país, a concentraçáo de contratos em culturas destinadas prioritariamente à exportação e a exclusão de amplos segmentos da agricultura familiar, sobretudo dos mais pobres (SOUZA et al., 2013, GRISA; WESZ JUNIOR; BUCHWEITZ, 2014). Diferentemente da maioria das análises de acesso ao Pronaf realizadas a partir do número de contratos, o estudo pelo número de Cadastros de Pessoa Física (CPF) dimensiona níveis inferiores de agricultores beneficiados pelo Programa, o que significa que o seu alcance em termos de famílias beneficiadas é menor. Isso se deve ao fato de muitos agricultores firmarem mais de um contrato ao longo de um ano (BÚRIGO; CAPELLESSO; CAZELLA, 2015). Os dados do Gráfico 2 indicam que, em 2013, teve-se 2.099.279 contratos de Pronaf, valor que representa 48,6\% dos estabelecimentos familiares brasileiros recenseados pelo IBGE em 2006. Contudo, quando se calcula essa relação a partir dos CPF dos agricultores beneficiados, esse total cai para 1.154.613, o que corresponde à somente $26,5 \%$ dos estabelecimentos familiares.

Para entender essa insuficiente capacidade de inclusão ao Pronaf, deve-se considerar que a universalização não estava entre os objetivos iniciais desse Programa, quando da sua criaçáo em 1996. O estudo sobre a agricultura familiar da época, que serviu de base para a estruturação do Pronaf, partiu da criaçáo de uma tipologia constituída por três categorias de agricultores familiares: a) consolidados: portadores de renda agropecuária elevada e capazes de sustentar seu próprio crescimento sem maior apoio do Estado; b) em transição: com grandes chances de se consolidar desde que o Estado aporte apoio via políticas públicas setoriais; e c) periféricos: com pouca perspectiva de 
permanecer no setor agropecuário, mesmo se beneficiados por políticas agrícolas. O relatório resumido desse estudo, publicado em 1994, sugeria a adoção de uma política de crédito rural específica que priorizasse os agricultores familiares considerados "em transição" no que se refere ao processo de modernização técnico-produtiva (GUANZIROLI, 1994).

Gráfico 2: Evolução Pronaf por quantidade de Cadastro de Pessoa Física (CPF) e número de contratos e sua relação com o total de Estabelecimentos Familiares (EF) - Brasil (1996 - 2013)

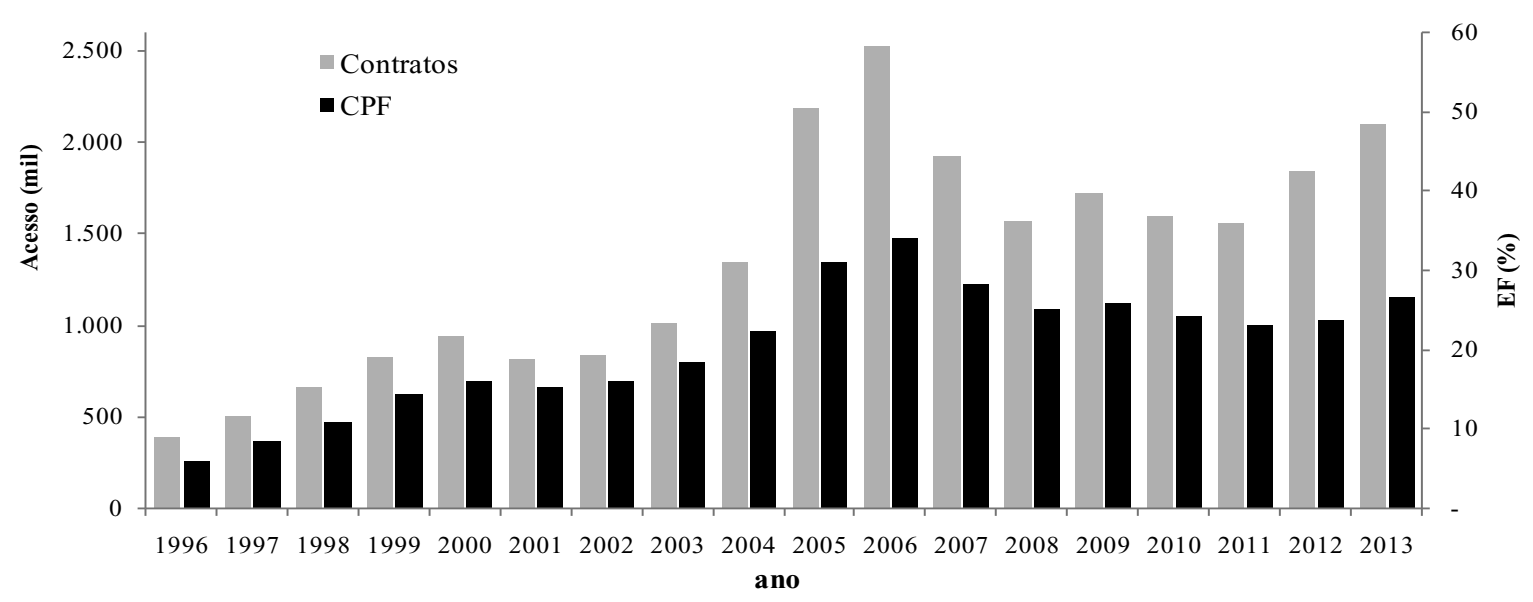

Fonte: Elaborado por Búrigo; Capellesso; Cazella (2015)a partir de dados do Banco Central do Brasil.

Naquele momento, uma franja de 35,7\% dos estabelecimentos agropecuários identificados como "periféricos" foi excluída do grupo a ser contemplado pelo Estado por meio das políticas de caráter produtivo, devendo ser atendida por políticas sociais. Ou seja, para esse público era essencial combater primeiramente as situaçóes de pobreza com outros tipos de políticas, para então construírem-se "portas de saída" em termos de produção e de inserção nos mercados. Essa visão, que limita as políticas públicas de natureza produtiva aos agricultores profissionais, continuou prevalente. Para Alves e Rocha (2010) e Buainain et al. (2014), trata-se de retardar via políticas sociais o fluxo descontrolado dessas famílias pobres para o meio urbano.

Uma linha de microcrédito voltada para os agricultores "periféricos" foi instituída em 1999 (Pronaf B), sem que se tenha tornado uma prioridade. Mesmo com a tentativa de ampliá-la durante o Governo Lula, os estudos apontam para a sua limitada capacidade de contribuir com a estruturação 
produtiva e a melhoria da renda (MAIA, et al., 2012). Aquino e Lacerda (2014) destacam a heterogeneidade de causas da pobreza rural, sendo que o Pronaf B volta-sesomente a uma dessas deficiências: a falta de acesso ao sistema financeiro. A necessidade de articular o crédito rural com políticas de assistência técnica e de educação, bem como de acesso a terra, água e tecnologias, já foi evidenciada nas análises e recomendaçôes pioneiras de Yunus e Jolis (2000). Esses autores destacam que o microcrédito, por si só, não resolve a situação de pobreza, sendo apenas um dos instrumentos para sair dela. E, se usado de forma equivocada, pode inclusive agravá-la. Desajustes na metodologia de aplicação dessa política de microcrédito agrícola geraram altos índices de inadimplência, especialmente nos anos iniciais de operação do Pronaf $\mathrm{B}^{13}$. Nessa direção, Zanie Costa (2014) aponta as deficiências dos serviços públicos de assistência técnica e extensão rural como o principal entrave para o êxito do Programa junto a segmentos mais pobres da agricultura familiar ${ }^{14}$.

$\mathrm{Na}$ atualidade, são também crescentes os questionamentos sobre a capacidade do Pronafem estimular um modelo de desenvolvimento agrícola alternativo que contraponha ao convencional, marcado pelo aumento da produtividade. Nenhuma contrapartida de natureza ambiental, por exemplo, é exigida dos beneficiários. Como a maioria dos acessos ao Pronaf atende agricultores integrados às principais cadeias produtivas e com maior movimentaçáo econômica, passou a ser recorrente a rotulaçáo do Programa como sendo uma política para o "agronegocinho". A modalidade do Pronaf criada especificamente para apoiar a agroecologia - conjunto de práticas e técnicas agrícolas que restringe o uso de insumos de síntese industrial e sementes geneticamente

13 A trajetória do Banco Popular do Brasil (BPB) espelha bem esse desajuste. O BPB foi constituído em 2003 como uma subsidiária do Banco do Brasil para operar linhas de microcrédito e outros serviços financeiros para populações de baixa renda, em áreas urbanas e rurais do país. Seus resultados operacionais foram tão sofriveis que o Banco do Brasil resolveu extingui-lo em 2008.

14 Especialmente no Nordeste, o Programa Brasil Sem Miséria, criado no Governo Dilma e coordenado pelo Ministério do Desenvolvimento Social e Combate à Fome (MDS), em parceria com o MDA, procurou combater a pobreza rural destinando recursos para agricultores abaixo da chamada linha da extrema miséria. Num primeiro momento, o Programa repassou recursos a "fundo perdido" $(R \$ 2.400,00)$ para cada família e prestou apoio técnico, com o objetivo de inclui-las posteriormente no Pronaf B. Segundo técnicos do MDA, entrevistados pelos autores no quadro de um projeto de pesquisa ainda em andamento, os resultados preliminares dessa iniciativa beneficiaram apenas 50 mil familias aproximadamente. Esse baixo alcance demonstra que, por diversas razões técnicas e de gestão, o programa não conseguiu estabelecer a "ponte" com o sistema de crédito produtivo, fazendo com que muitas familias de agricultores não saissem da precária condição socioeconômica em que vivem. 
modificadas, além de privilegiar os chamados mercados de proximidade - permanece residual e sem grande aderência da maioria dos agricultores familiares.

Diante dos desafios sociais contemporâneos, Castel (2009) destaca que o Estado Social necessita incorporar um papel ativo, que passaria pela descentralização de recursos e serviços com vistas a tratar das situaçóes locais e trajetórias pessoais. Ao entender que a descentralização não é um bem em si mesmo, o autor defende que sua aplicaçáo deva vir associada à criaçáo de mecanismos de contrapartida, com foco nas capacidades dos indivíduos, tratando-os como sujeitos com direitos e deveres. Em síntese, ao beneficiário da ação pública, deve-se prever um esforço que evite a automatização do acesso, com o objetivo de reforçar as capacidades de se tornar responsável para conduzir a sua própria vida. No caso do Pronaf, prevalece, no entanto, a orientação de inclusão ao produtivismo modernizante de uma parcela da agricultura familiar, relegando à ampla maioria, os considerados inaptos à modernização, políticas sociais com o propósito de retardar o êxodo rural.

\subsection{As políticas de mercados institucionais para a agricultura}

\section{familiar}

A temática da segurança alimentar e nutricional se tornou um problema político assumido pela sociedade brasileira desde o final da década de 1980 . No início dos anos 1990 surgiu a campanha "Ação da Cidadania contra a Fome, a Miséria e pela Vida", que contou com a participação de comitês locais da sociedade civil organizada, compostos,em sua maioria, por lideranças comunitárias. Essa iniciativa ganhou mais destaque a partir de 2003, com a criação do Programa Fome Zero (HESPANHOL, 2013). Esse programaconsiste em um conjunto de estratégias impulsionado pelo Governo Federal para assegurar o direito à alimentaçáo de pessoas com dificuldades de acesso aos alimentos. Para tanto, ações complementares foram instituídas orientadas por quatro eixos articuladores de proteção e promoçáo social: ampliação do acesso aos alimentos; fortalecimento da agricultura familiar; geração de renda; e articulação, mobilização e controle social (MENEZES; SANTARELLI, 2013). Nesse último aspecto, destaca-se a rearticulação do Conselho Nacional de Segurança Alimentar e Nutricional (Consea), estrutura gestora de caráter participativo que elaborou as bases do PNAE e PAA. 
O PNAE, conhecido como "merenda escolar", foi inspirado em ideias concebidas no início da década de 1940. Naquela época, o Instituto de $\mathrm{Nu}$ trição da Universidade do Brasil, atual Instituto de Nutrição Josué de Castro da Universidade Federal do Rio de Janeiro, defendia a proposta de que o Governo Federal precisa oferecer alimentação aos estudantes das escolas públicas (BRASIL, 2011) ${ }^{15}$. Em 1955, foi instituída a Campanha de Merenda Escolar, vinculada ao Ministério da Educação. Inicialmente, o programa atendia algumas escolas em áreas de vulnerabilidade social, mas com o passar do tempo foi ganhando abrangência nacional. A sua operacionalização foi se transformando e adquirindo distintas denominaçóes, de modo que, em 1979, passou a ser chamado de Programa Nacional de Alimentaçáo Escolar.

Em 1988, com a promulgação da nova Constituição Federal, o direito à alimentação escolar foi assegurado a todos os alunos do ensino fundamental por meio do programa suplementar de alimentação escolar, a ser realizado pelos governos federal, estaduais e municipais. Inicialmente, a execuçáo desse programa se deu de forma centralizada, na qual o órgáo gerenciador planejava cardápios padronizados, adquiria os gêneros por processo licitatório, contratava laboratórios especializados para efetuar o controle de qualidade e ainda se responsabilizava pela distribuição dos alimentos em todo o território nacional. Esse modelo de gestáo apresentava diversos pontos negativos, tais como: alto custo de transporte para distribuição dos alimentos em todo o país; cardápios não condizentes com os diferentes hábitos alimentares das distintas regióes; e a grande quantidade de alimentos processados em função da necessidade de prazos de validade mais extensos, com o consequente monopólio de mercado (BRASIL, 2011).

Em face dessas dificuldades, em 1994, foi instituída a descentralização do PNAE. A transferência de recursos passou a ser feita diretamente do Governo Federal aos estados federados e municípios, sem a necessidade de celebraçáo de convênios ou quaisquer outros instrumentos similares, o que permitiu maior agilidade ao processo. A partir de então, estados e municípios ficaram responsáveis por elaborar o cardápio, adquirir alimentos, realizar o controle

15 Nascido em 1908 no Estado de Pernambuco, Josué de Castro foi autor de inúmeras obras que apresentavam ideias revolucionárias para sua época. Médico, professor, geógrafo, sociólogo e político, Josué fez da luta contra a fome o seu principal tema de trabalho (ALVES, 2007). 
de qualidade, contratar os recursos humanos necessários, como merendeiras e nutricionistas, e providenciar a infraestrutura física adequada para a realização das refeiçóes. Em 2009, ocorreram avanços na concepção do Programa, em especial, com a adoçáo do enfoque de desenvolvimento territorial proposto pelo Consea, fortalecendo a inclusão de alimentos produzidos regionalmentena merenda escolar, além de prever maior envolvimento das organizaçóes sociais locais na sua gestão. Essa mudança garantiu que, no mínimo, 30\% dos repasses do Fundo Nacional de Desenvolvimento da Educação (FNDE) sejam investidos na aquisição de produtos da agricultura familiar da região, priorizando assentamentos de reforma agrária, comunidades tradicionais, indígenas e comunidades quilombolas (FNDE, 2015). Em síntese, abriram-se novas possibilidades para adaptar o cardápio aos hábitos alimentares locais e fortalecer a agricultura familiar via oportunidades de mercado.

Instituído em 2003 e regulamentado em 2008, o PAA tem como principais finalidades a promoçáo do acesso à alimentaçáo e o incentivo à agricultura familiar. Para tanto, o Programa prevê a compra de alimentos produzidos por agricultores familiares, assentados da reforma agrária, silvicultores, aquicultores, extrativistas, pescadores artesanais, indígenas, integrantes de comunidades remanescentes de quilombos rurais e demais povos e comunidades tradicionais que atendam aos critérios de enquadramento da Lei da Agricultura Familiar (BRASIL, 2015a). Esse Programa é financiado com recursos provenientes do Governo Federal e suaexecução fica a cargo dos estados federados e dos municípios, em parceria com a Companhia Nacional de Abastecimento (Conab). Por meio de distintos mecanismos, os produtosdo PAA são adquiridossem a necessidade de licitaçáo. De acordo com a necessidade,os alimentos são transferidos a bancos de alimentos, doados a instituiçóes assistenciais e distribuídos, por meio de cestas básicas, às populaçóes em situaçóes de risco alimentar. São também distribuídos para as escolas públicas, como forma de complementar o PNAE. O excedente é encaminhado aos programas sociais e para ser comercializado em leilóes públicos.

No que se refere ao PNAE, até 2014, o limite individual de venda do agricultor familiar para a alimentaçáo escolar era de $\mathrm{R} \$ 20$ mil por ano. Por sua vez, o PAA prevê que cada agricultor venda até $\mathrm{R} \$ 6,5$ mil por ano na modalidade de Compra com Doação Simultânea, considerada a mais recorrente. Em operaçóes realizadas por meio de organizaçóes sociais, esse limite sobe para $\mathrm{R} \$ 8$ mil. 
Para acessar essas políticas públicas, os agricultores familiares fornecedores podem ser representados por uma organização social (cooperativa ou associaçáo) ou realizar seu projeto de venda de maneira individual, mediante a apresentação de Declaração de Aptidão ao Pronaf (DAP). Em ambas as políticas públicas, os agricultores familiares organizados formalmente são priorizados na seleção de projetos de venda. Essa priorização também ocorre com relação aos alimentos orgânicos e agroecológicos. No PAA, esses alimentos podem receber um acréscimo de até $30 \%$ em relaçáo ao preço dos alimentos convencionais ${ }^{16}$.

A dimensão extremamente seletiva desse acesso é mais bem compreendida quando se sabe que os agricultores pobres raramente integram organizaçóes formais, o que dificulta o acesso às informaçóes e à viabilidade logística para atuar nesses programas. $\mathrm{O}$ quadro é mais grave devido aos baixos índices de sindicalização e às deficiências da assistência técnica em termos de efetividade e de capacidade para atender esse público, o que exclui a maior parte dos agricultores familiares. Além disso, com intuito de simplificar as suas tarefas, os funcionários das prefeituras preferem adquirir alimentos de fornecedores de maior porte. A Tabela 2, a seguir, evidencia os volumes de recursos investidos tanto no PAA quanto no PNAE entre os anos de 2010 e 2014 no Brasil, o número de beneficiários fornecedores do PAA e o valor médio anual destinado por agricultor para o PAA.

Considerando o número de estabelecimentos agrícolas familiares registrados pelo Censo Agropecuário de 2006, os dados indicam o baixo número de fornecedores do PAA frente à significativa quantidade de unidades agrícolas familiares existentes no país. No ano de 2012, quando se teve o maior número de agricultores contemplados por essa política (185.979), apenas 4,3\% dos estabelecimentos da agricultura familiar tiveram acesso ao programa. De forma semelhante, é possível afirmar que os volumes totais investidos na compra de produtos da agricultura familiar via PNAE também contemplam uma pequena parcela desse segmento. $\mathrm{Na}$ ausência de informaçóes efetivas a respeito do número de agricultores fornecedores, elaborou-se uma estimativa a partir do limite de valores individuais. No ano de 2014, caso o montante total de R\$

16 Nesse caso, para contar com o acréscimo de 30\% no preço desses produtos é necessário que o agricultor tenha certificação de conformidade orgânica. 
1,10 bilhão fosse distribuído pelo limite individual de $\mathrm{R} \$ 20$ mil, 55.395 agricultores fornecedores de alimentos seriam contemplados. $\mathrm{Ou}$, ainda, ao se tomar por base o valor teto de R $\$ 6,5$ mil, utilizado pelo PAA, o alcance seria, no máximo, de 169.230. Não se pode esquecer que, na maioria dos casos, os agricultores fornecedores do PNAE também participam do PAA. Além disso, ambas as políticas demandam infraestrutura básica e estratégias de logística inexistentes na maior parte das unidades agrícolas familiares, revelando que,atualmente, essas políticas apresentam obstáculos praticamente instransponíveis para a maior parte dos agricultores familiares.

Tabela 2: Volume de recursos investido na compra de produtos da agricultura familiar no PAA e PNAE, número de beneficiários fornecedores do PAA e valor médio anual destinado por agricultor familiar no PAA (2010-2014)

\begin{tabular}{ccccc}
\hline Ano & $\begin{array}{c}\text { Palor total } \\
\text { investido na } \\
\text { compra de } \\
\text { produtos da } \\
\text { agricultura } \\
\text { familiar (R\$) }\end{array}$ & $\begin{array}{c}\text { Número de } \\
\text { beneficiários } \\
\text { fornecedores }\end{array}$ & $\begin{array}{c}\text { Valor médio } \\
\text { anual destinado } \\
\text { por agricultor } \\
\text { familiar (R\$) }\end{array}$ & $\begin{array}{c}\text { Valor total investido na } \\
\text { compra de produtos da } \\
\text { agricultura familiar (R\$) }\end{array}$ \\
\hline 2010 & $680.750 .000,00$ & 155.166 & $4.387,24$ & $910.200 .000,00$ \\
2011 & $667.325 .490,15$ & 160.011 & $4.170,50$ & $915.300 .000,00$ \\
2012 & $839.217 .997,38$ & 185.979 & $4.512,43$ & $991.800 .000,00$ \\
2013 & $443.185 .235,52$ & 96.912 & $4.573,07$ & $1.062 .600 .000,00$ \\
2014 & $536.523 .718,18$ & 107.120 & $5.008,62$ & $1.107 .900 .000,00$ \\
\hline
\end{tabular}

* O número total de agricultores familiares fornecedores do PNAE é de

difícil mensuração, devido à inexistência de um sistema de controle e acompanhamento unificado dessa política. Fonte: Adaptada de Brasil (2015a).

\section{Os programas de natureza assistenciais: os casos da Previdência Social Rural e do Bolsa Família}

O tema da previdência social rural foi incluído nesta análise por se tratar da principal política social e de distribuição de renda no meio rural brasileiro. Considerado por Delgado (2015) o "vagáo tardio do direito social trabalhista brasileiro", o sistema previdenciário dos agricultores familiares foi 
ampliado com a Constituição de 1988 e aplicado de fato a partir de 1992. Até então,prevalecia o chamado Fundo de Assistência e Previdência do Trabalhador Rural (Funrural), criado em 1971, que assegurava o direito de aposentadoria especial somente ao chefe do estabelecimento e no valor de meio salário mínimo. Após a nova Constituição, esse direito foi estendido ao cônjuge, no valor de um salário mínimo por beneficiário.

Ao longo das duas décadas de vigência do sistema da Previdência Rural, verifica-se que esse sistema de direito social, combinado com a política de valorização do salário mínimo, tem efetivo impacto distributivo para as famílias rurais. Essa política irá alterar o padrão de distribuição da renda familiar, independentemente das condições produtivas dos estabelecimentos rurais familiares. (DELGADO, 2015, p. 436).

As agricultoras e agricultores acessam a aposentadoria por idade, respectivamente, aos 55 e 60 anos, ficando ainda assegurados os auxílios doença e maternidade. A Tabela 3 revela que, em meados de 2013, existiam no Brasil quase nove milhôes de benefícios previdenciários destinados à categoria de agricultores familiares. A estimativa é que cerca de 5,3 milhôes de famílias sejam contempladas na condiçáo de "segurado especial", por ser ou ter sido agricultor durante a vida ativa ${ }^{17}$. Essa denominação se deve ao fato das contribuiçóes dos agricultores familiares ao fundo da previdência social serem largamente deficitárias. A estimativa efetuada por Cazella (2007) indica que a contribuição efetuada pelos agricultores náo chega a $15 \%$ do montante pago em forma de benefícios previdenciários a essa categoria social. Note-se que o total de 5,3 milhóes de famílias de agricultores atendidas pelos serviços previdenciários é superior aos 5,1 milhões de estabelecimentos agropecuários registrados no último censo. Infelizmente, não existe no Brasil um sistema de cadastro e de informaçóes das unidades produtivas que permita identificar, por exemplo, quantos desses agricultores continuam à frente de estabelecimentos, tendo ou não sucessor para a unidade agrícola familiar. E nem a quantidade de agricultores aposentados que deixaram o espaço rural e não mais residem nas suas antigas unidades produtivas.

17 A diferença entre nove milhões de beneficiados e 5,3 milhões de familias se explica pelo fato de que cada familia pode ter mais de um beneficiário da previdência social rural. 
Tabela 3: Alguns indicadores gerais dos benefícios previdenciários (1991-2013)*

\begin{tabular}{lccc}
\hline Anos & $\begin{array}{c}\text { Número total } \\
\text { de benefícios } \\
\text { acumulados (mil) }\end{array}$ & $\begin{array}{c}\text { Valor unitário } \\
\text { dos benefícios em } \\
\text { salário mínimo } \\
\text { (US\$) }\end{array}$ & $\begin{array}{c}\text { Número de famílias } \\
\text { contempladas (mil) }\end{array}$ \\
\hline 1991 (Funrural) & $4.080,4$ & 22,0 & - \\
1992 & $4.976,9$ & 47,1 & $2.971,28$ \\
1995 & $6.359,2$ & 100,7 & $3.976,53$ \\
2000 & $6.493,9$ & 82,50 & $3.876,96$ \\
2005 & $7.351,2$ & 123,50 & $4.388,78$ \\
2010 & $8.372,1$ & 311,80 & $4.998,27$ \\
2013 (junho) & $8.909,35$ & 300,00 & $5.319,00$ \\
\hline
\end{tabular}

*Dados obtidos no Anuário Estatístico da Previdência Social (vários anos) e Boletim Estatístico de Previdência Social (julho de 2013). Fonte: Delgado (2015). ${ }^{18}$

Tem-se aqui um vasto campo de pesquisa sobre a "polarização e mobilidade cíclica" das unidades agrícolas familiares, fenômeno analisado por Shanin (1972) tendo por base o campesinato russo. A partir dos chamados estudos dinâmicos - "[...] tipo de investigação em que se analisa a mobilidade socioeconômica, configurando a evolução histórica das unidades domésticas camponesas individuais" (SHANIN, 1972, p. 324)-, esse autor identificou quatro tipos de mobilidades das unidades agrícolas familiares, extremamente complexas, que formam a base do processo de diferenciação social dessas unidades. Esse minucioso acompanhamento das unidades produtivas existentes na Rússia do final do século XIX, o qual propiciou as formulações teóricas dos neopopulistas russos, tendo Chayanov à frente, contrasta com a precariedade e, sobretudo, a fragmentação de informações existentes no Brasil, o que dificulta o acompanhamento das políticas públicas atualmente em curso.

Além da previdência social rural, o Programa Bolsa Família tornou-se uma referência no quadro das políticas sociais do país. A partir de 2003, o enfrentamento da pobreza via intervençáo pública enfatizou as políticas de

18 A relação de 1,675 benefícios por família, utilizada para estimar o número de famílias de agricultores contempladas pela previdência social, foi calculada a partir de pesquisa coordenada por Delgado e Cardoso (2000) em 300 municípios das regiões Nordeste e Sul do país. 
segurança alimentar. Primeiramente, foi implantado um conjunto de políticas previstas no Programa Fome Zero, cujo objetivo principal consistiu em garantir o direito à alimentação adequada às pessoas com dificuldades de acesso aos alimentos. O PBF, principal ação do Programa Fome Zero, foi instituído em outubro de 2003, vinculado inicialmente à Presidência da República (COHN, 2012). A partir de 2004, esse Programa foi transferido para a Secretaria Nacional de Renda e da Cidadania, do Ministério de Desenvolvimento Social e Combate à Fome.

Em julho de 2016, o Programa Bolsa Família passou a considerar pobres as famílias com renda mensal per capita entre $\mathrm{R} \$ 85,01$ e $\mathrm{R} \$ 154,00$, e extremamente pobres as que possuem renda mensal per capita inferior a $\mathrm{R} \$ 85,00$. Atualmente, o PBF está calcado em três eixos: i) transferência de renda via repasse de recursos monetários para aliviar imediatamente a pobreza; ii) as condicionalidades, que são os compromissos assumidos tanto pelas famílias beneficiárias quanto pelo Estado, visando ampliar o acesso dessas famílias aos seus direitos sociais básicos nas áreas de saúde, educação e assistência social; e iii) as açôes e programas complementares, que objetivam contribuir para que as famílias beneficiárias superem a condição de pobreza ${ }^{19}$. De acordo com o Portal da Transparência, em 2014, o Governo Federal destinou aproximadamente R \$ 27,2 bilhões ao PBF, distribuídos entre 14,1 milhóes de famílias beneficiárias, o que representa uma média mensal de $\mathrm{R}$ 161,00 por família (BRASIL, 2015c).

Desde 2001, o MDS utiliza um cadastro unificado como ferramenta para identificar, armazenar e atualizar as informaçóes declaradas por famílias de baixa renda ${ }^{20}$. Denominado de CadÚnico, esse sistema vem sendo aperfeiçoado a partir da implantaçáo do PBF, com o objetivo principal de conhecer melhor as populações empobrecidas. A identificação de famílias pertencentes a Grupos Populacionais Tradicionais ou Específicos (GPTE), iniciada em 2005, foi mobilizada neste artigo com o propósito de avaliar o número de

19 Os valores repassados variam de acordo com a situação familiar, havendo dois tipos de benefícios. O tipo básico é dado às familias que contam comum a renda mensal de até $R \$ 85,01$ porpessoa. Nesses casos, 0 valor do auxilio concedido atualmente é de $R \$ 85,00$ por mês. O benefício variável é oferecido às familias que possuam em sua composição mulheres grávidas, mães que se encontram em fase de amamentação elou crianças e adolescentes entre 0 e 16 anos de idade. 0 valor atual de cada um desses benefícios é de $R \$ 39,00$ e cada familia pode obter até cinco deles por mês, chegando aos $R \$ 195,00$.

20 São consideradas familias de baixa renda as que recebem mensalmente até meio salário mínimo por pessoa. ou um total de até três salários minimos. 
agricultores familiares beneficiados pelo Bolsa Família. De acordo com a Tabela 4, a seguir, é possível perceber que, no final de 2014, as famílias contempladas pelo Programa integravam 15 grupos distintos.

Tabela 4: Número de famílias beneficiadas pelo Programa Bolsa Família, por grupos populacionais tradicionais ou específicos (dez. 2014)

\begin{tabular}{lcc}
\hline Populações específicas & $\mathbf{N}^{\circ}$ de familias & \% \\
\hline Agricultoresfamiliares & 636.861 & 4,54 \\
Assentadas da reforma agrária & 64.847 & 0,46 \\
Beneficiáriaspelo PNCF & 2.316 & 0,02 \\
Extrativistas em zonas de floresta & 24.021 & 0,17 \\
Pescadores artesanais & 89.185 & 0,64 \\
Quilombolas (comunidades de descendentes de escravos) & 99.372 & 0,71 \\
Ribeirinhas & 57.085 & 0,41 \\
Acampadas (a serem beneficiadas pela reforma agrária) & 12.682 & 0,09 \\
Subtotal (categoria de agricultores familiares) & $\mathbf{9 8 6 . 3 6 9}$ & $\mathbf{7 , 0 4}$ \\
Atingidas por empreendimentos de infraestrutura & 4.277 & 0,03 \\
Catadoras de materialreciclável & 29.085 & 0,21 \\
Ciganas & 2.438 & 0,02 \\
Com pessoa presa no sistema carcerário & 6.046 & 0,04 \\
Emsituação de rua & 23.546 & 0,17 \\
Indígenas & 107.779 & 0,77 \\
Pertencentes à comunidade de terreiro & 2.491 & 0,02 \\
Sub-Total (categoria GPTE) & 1.162 .031 & 8,29 \\
\hline Total Brasil & 14.014 .252 & 100,00 \\
\hline
\end{tabular}

*O Programa Nacional de Crédito Fundiário (PNCF) é uma política pública complementar à reforma agrária, que empresta recursos financeiros para que agricultores seme com pouca terra adquiram áreas ofertadas no mercado. Fonte: Brasil (2015b).

A análise a respeito dos GPTE rurais beneficiários pelo PBF foi realizada com base nos dados disponibilizados pelo CadÚnico, referentes ao mês de dezembro de 2014. As informaçóes sobre o número de famílias beneficiadas pelo Bolsa Família pertencentes a cada um dos GPTE devem ser tomadas, no entanto, com precaução, pois podem existir distorçóes em relação a outras 
fontes. Como exemplo, o número de agricultores familiares assentados pela reforma agrária registrados no CadÚnico foi de 64.847, enquanto o Instituto Nacional de Colonização e Reforma Agrária identificou 415.560 famílias assentadas beneficiadas pelo PBF em 2013 (INSTITUTO NACIONAL..., 2015). Esse montante representa 31,5\% do total de famílias assentadas.Uma explicação para essa diferença de informação pode residir no fato de agricultores assentados pela reforma agrária se autodeclararem agricultores familiares e, dessa forma, terem sidos incluídos nessa categoria específica do CadÚnico e não na categoria de "assentadas da reforma agrária”.

A partir dos dados da Tabela 4, verifica-se que, em dezembro de 2014, as famílias de agricultores beneficiadas pelo PBFque pertencem a algum GPTE representavam 7\% do total de famílias beneficiadas pelo Programa (986.369 famílias $)^{21}$. Esse montante equivale a 22,5\% das unidades agrícolas familiares recenseadas em 2006. Ou seja, um quarto dos agricultores familiares brasileiros depende da principal política de enfrentamento da pobreza para sobreviver e, em sua ampla maioria, não acessa as políticas de crédito agropecuário e de mercados institucionais.

\section{Conhecer mais para melhor intervir}

As informaçóes referentes à quantidade de agricultores familiares beneficiados pelas políticas públicas discutidas anteriormente são comparadas neste tópico com o propósito de demonstrar a prevalência de uma dicotomia entre as ações públicas de caráter produtivo e aquelas cuja finalidade principal é o assistencialismo social. A análise de conjunto de políticas públicas, aqui realizada, revela a existência de um número significativo de unidades agrícolas familiares que se encontra numa situação de obscuridade. Isto é, pouco se conhece sobre suas principais estratégias de reprodução social e projetos de futuro. Esses agricultores familiares totalizam cerca de dois milhóes que, somados aos seus pares beneficiados pelo Bolsa Família (quase um milhão), representam um contingente expressivo de agricultores que não integra a agenda

21 As familias indigenas não foram consideradas para fins desta análise como sendo agricultoras familiares, embora possam ser recenseadas como unidades agrícolas familiares caso tenham realizado produção agropecuária no período censitário (INSTITUTO BRASILEIRO..., 2007). O mesmo raciocínio se aplica para a categoria "Atingidas por empreendimentos de infraestrutura", o que subestima o número total de agricultores familiaresbeneficiados pelo PBF. 
de trabalho das principais organizaçóes profissionais agrícolas (OPA) ${ }^{22}$. Para facilitar a compreensão dessa demonstração, a Tabela 5, a seguir, sintetiza os principais números dos estabelecimentos agropecuários brasileiros segundo o acesso a políticas públicas específicas.

Tabela 5: Quantidades de unidades agrícolas recenseadas em 2006, segundo o enquadramento a políticas públicas produtivas e assistenciais

\begin{tabular}{lc}
\hline Itens & Quantidade $\mathbf{( n}^{\mathbf{0}} \mathbf{)}$ \\
\hline Total de estabelecimentos agropecuários & 5.175 .489 \\
Unidades agrícolas não familiares & 807.587 \\
Unidades agrícolas familiares (UAF) & 4.367 .902 \\
UAF enquadradas nas normas do Pronaf & 4.082 .926 \\
UAF não enquadradas no Pronaf & 284.976 \\
Beneficiadas pelo Pronaf, PNAE e PAA & 1.154 .613 \\
Beneficiadas pela Reforma Agrária & 1.320 .463 \\
Famílias beneficiadas pela Previdência Social Rural & 5.319 .000 \\
Famílias beneficiadas pelo Bolsa Família & 986.369 \\
\hline
\end{tabular}

Fonte: Instituto Brasileiro de Geografia e Estatística(2009) e fontes citadas nos quadros anteriores, relacionados a cada política pública; adaptado pelos autores.

Uma parcela de agricultores familiares que acessa o crédito agrícola subsidiado do Pronaf também se beneficia das políticas de compras institucionais de alimentos (PNAE e PAA). Esses agricultores, supostamente, possuem condiçóes de atender às exigências sanitárias e a escala de produção de alimentos presentes nas normas desses programas. Para efeito de análise, considerou-se, aqui, que esse grupo de agricultores do PAA e PNAE está incluído no total de $\mathrm{CPF}$ atendidos pelo Pronaf (linha F da Tabela 5). Acredita-se que o número de agricultores familiares que participam do PAA e PNAEe não acessam o referido programa de crédito, seja desprezível ou nulo.

Assim, esse contingente de 1.154 .613 agricultores familiares, somado aos 284.976 que não se enquadram nas normas do Pronaf por apresentarem

22 Tendo como referencia o estudo de Maresca (1983) sobre as organizações profissionais agrícolas existentes da França, pode-se conceber como as principais OPA brasileiras: os serviços públicos de extensão rural (inclusive aqueles prestados por cooperativas agricolas e ONG), os movimentos sindicais e sociais rurais, além dos bancos públicos e das cooperativas de crédito que operam as politicas de crédito rural. 
rendas acima do teto previsto pelo Programa, totalizam 1.439.589 (F + E) unidades produtivas. Juntos, esses agricultores familiares integram as redes sociotécnicas que dão sustentaçáo às principais organizaçóes que atuam junto à agricultura familiar no país. Eles certamente são sindicalizados, recebem de algum modo orientaçóes técnicas de agências públicas e privadas e seus sistemas produtivos se voltam para mercados competitivos, com os quais têm uma integração regida por normas relativamente formais e transparentes. Nesse grupo, também se encontram os adeptos aos preceitos da agricultura orgânica ou da agroecologia, na maioria das vezes, assessorados por organizaçôes não governamentais.

Outro estrato extremo é constituído por 986.369 agricultores familiares (linha I da Tabela 5) que recebem o Programa Bolsa Família e dos quais, até recentemente, quase nada se conhecia de suas estratégias de reprodução social e as características socioeconômicas das suas unidades produtivas. Esse grupo náo representa o público preferencial das organizaçóes rurais que se ocupam da produção agropecuária. Entre esses dois extremos, têm-se 1.941.944 famílias de agricultores $[\mathrm{D}-(\mathrm{F}+\mathrm{I})]$ dos quais, a exemplo dos beneficiados pelo Bolsa Família, também pouco se sabe sobre suas orientaçôes técnico-produtivas. Nesse grupo, provavelmente, encontra-se uma parcela importante de beneficiários da política de Previdência Social Rural e mesmo da Reforma Agrária que, como se viu, são políticas que concernem um número expressivo de famílias, respectivamente, 5.319.000 (H) e 1.320.463 (G).

A elevada taxa de $71,7 \%$ de agricultores familiares que não acessam a principal política pública implantada pelo MDA (Pronaf) merece ser analisada de forma mais aprofundada. Se, por um lado, a dependência da trajetória das principais organizaçóes profissionais agrícolas, as quais permanecem apegadas ao modelo de agricultura difundido nos anos 1960 e 1970, explica parte dessa situação, por outro lado, não se pode atribuir tanto peso explicativo a um único elemento. Existem aqui outras dificuldades relacionadas ao alcance limitado em termos de mobilização e de representaçáo social proporcionado por essas organizaçóes profissionais. Uma parcela importante da populaçáo rural continua distante dos processos mais tradicionais de apoio oferecidos pelo Estado, mantendo-se um hiato entre as demandas gerais de parcela importante da população do campoea capacidade das organizaçóes e dos gestores públicos canalizarem essas aspiraçóes em termos de recursos. Tal descompasso 
gera aquilo que Hamel eWarin (2014) definem como o "não recurso" a determinadas políticas públicas ${ }^{23}$. Essa situação pode ocorrer por diversos fatores, como falta de conhecimento da oferta pública, discriminação, estigmatização social, isolamento do potencial beneficiário, problemas de funcionamento dos serviços públicos responsáveis, mas também por falta de interesse dos possíveis beneficiários.

\section{Considerações finais}

O foco principal deste artigo consistiu em analisar de forma conjunta os resultados das principais políticas públicas de apoio à agricultura familiar, tomando por baseo número de beneficiados. Esse tipo de análise tenta colaborar para se cobrir uma lacuna presente nas pesquisas sobre o acesso dessa categoria social às políticas públicas, pois, na maioria dos casos, estuda-se uma política isoladamente, sem avaliar o grau de integração do universo das unidades agrícolas familiares às distintas açóes do Estado. Em linhas gerais, os resultados demonstram que, não obstante os avanços alcançados nos últimos 25 anos na concepção de políticas públicas específicas para agricultura familiar brasileira, três aspectos se sobressaem nesse processo: a polarização das ações, separando as políticas entre as de natureza produtiva e as de caráter assistencial, as dificuldades de se ampliar o público contemplado pelas políticas orientadas para o fomento da produçáo agropecuária e a inexistência de contrapartidas socioambientais para aqueles que se beneficiam de subsídios públicos.

O primeiro e o segundo aspectos estão diretamente associados ao profundo desconhecimento das OPA e das organizaçóes de pesquisa acerca das unidades agrícolas que não se enquadram nos modelos de desenvolvimento agrícola difundidos, seja convencional, seja de orientação agroecológica. Os dados quantitativos apresentados neste artigo revelam que inexiste no Brasil um sistema de informaçóes relativo aos estabelecimentos agropecuários, que não se limite apenas à condiçẫo de posse e uso das terras. Isto é, para se superar as debilidades acima apontadas é fundamental a construção de ferramentas inovadoras, capazes de incorporar informações referentes às finalidades e orientaçóes técnico-produtivas das unidades rurais, bem como

23 Hamel e Warin (2014) calculam a Taxa de Não Recurso a partir da relação entre o total de beneficiários de determinada política pública pelo total de potenciais beneficiários. 
dos seus acessos às distintas políticas públicas. Incluem-se neste rol as unidades agropecuárias, de lazer, conservacionistas, as familiares e não familiares, as agroecológicas e convencionais, as tradicionais, as mistas, as pluriativas ou monoativas, as com ou sem sucessores.

Esse tipo de base de dados é incontornável para que se avance na estratégia defendida por Castel (2009) de um Estado social ativo que, dentre outros aspectos, associe a destinaçáo de subsídios públicos ao oferecimento de contrapartidas para a sociedade por parte de seus beneficiários. Mesmo com a completa ausência desse tipo de discussão no que se refere às benesses do Estado brasileiro para o agronegócio, nada justifica que as organizaçóes implicadas com a agricultura familiar não avancem no sentido de atrelar subvençóes públicas a retornos para a sociedade. Esses avanços devem se materializar em contrapartidas relacionadas à proteção e conservação ambiental, manutenção da biodiversidade, ofertas de produtos isentos de agrotóxicos e de sementes geneticamente modificadas e de serviços associados às amenidades rurais, além da valorização do patrimônio sociocultural específico de cada região.

Por fim, algumas questóes referentes às famílias que não participam das políticas públicas produtivas permanecem em aberto: em que medida agricultores aposentados ou prestes a se aposentar e que náo dispóem de herdeiros para dar continuidade à atividade agropecuária têm interesse em continuar investindo financeiramente nas suas unidades produtivas? Que destino está sendo dado aos estabelecimentos agropecuários sem sucessor, cujos responsáveis estão aposentados ou em vias de se aposentar? As respostas a essas indagaçóes passam pela necessidade de rever as orientaçóes e as normas operacionais das políticas produtivas e das agências responsáveis pelas suas operacionalizaçóes que, por sua vez, carecem de informaçóes qualificadas baseadas em estudos regionalizados. Se as agências de desenvolvimento rural desconhecem e não priorizam esses estratos da agricultura familiar brasileira, do lado da pesquisa esse quadro não é diferente e a escassez de informaçóes sobre esses agricultores é uma forte evidência dessa situação. 


\section{Referências}

ALVES, E.; ROCHA, D. de P. Ganhar tempo é possível? In: GASQUES, J. G.; VIEIRA FILHO, J. E.; NAVARRO, Z. (Org.). A agricultura brasileira: desempenho, desafios e perspectivas. Brasília: IPEA, 2010. p. 275-290.

ALVES, J. J. A. Una leitura geográfica da fome com Josué de Castro. Revista de Geografia Norte Grande, Santiago, n. 38, dez. 2007. Disponível em: <http://www.scielo.cl/scielo. php?script=sci_arttext \&pid=S0718-34022007000200001\&lng=es\&nrm=iso $>$. Acesso em: 23 abr. 2015.

AQUINO, J. R.; LACERDA, M. A.D. Magnitude e condiçóes de reprodução econômica dos agricultores familiares pobres no semiárido brasileiro: evidências a partir do Rio Grande do Norte, Revista de Economia e Sociologia Rural, v.52, supl. 1, p. 167-188, 2014. Disponível em: <http://dx.doi.org/10.1590/S0103-20032014000600009>. Acesso em: 8 mar. 2015.

BRASIL. Lei no 11.326, de 24 de julho de 2006. Estabelece as diretrizes para a formulação da Política Nacional da Agricultura Familiar e Empreendimentos Familiares Rurais. Diário Oficial da República Federativa do Brasil, Brasília, DF, 25 jul. 2006. Disponível em: <http://www.planalto.gov.br/ccivil_03/_ato2004-2006/2006/lei/111326.htm>. Acesso em: 15 mar. 2015.

Fome Zero: conceito. 2011. Disponível em:<http://www.fomezero.gov.br/o-que-e>. Acesso em: 14 fev. 2011.

Cadastramento diferenciado: diversidade no Cadastro Único - respeitar e incluir. Brasília: Ministério do Desenvolvimento Social e Combate à Fome, 2014.

Ministério do desenvolvimento social e combate à fome. Programa Nacional de Alimentaçáo Escolar. Brasília: 2015a. Disponível em: <http://www.fnde.gov.br/programas/ alimentacao-escolar/alimentacao-escolar-historico>. Acesso em: 14 mar. 2015.

Bolsa Família: relatório de informaçóes sociais. Brasília: MDS, 2015b. Disponível em: <http://www.mds.gov.br/bolsafamilia>. Acesso em: 15 mar. 2015.

Portal da transparência. 2015c. Disponível em: <http://www.portaltransparencia. gov.br/PortalTransparenciaPesquisaAcaoUF.asp? $\operatorname{codigoAcao}=8442 \& \operatorname{codigoFuncao}=08 \&$ No meAcao $=$ Transfer $\%$ EAncia + de + Renda + Diretamente $+\% E 0 s+F a m \% E D l i a s+e m+C o n d i \% E 7$ $\%$ E3o+de+Pobreza+e+Extrema+Pobreza+\%28Lei+n\%BA+10\%2E836\%2C+de+2004\%29\& Exercicio=2014>. Acesso em: 13 maio 2015.

BUAINAIN, A. M. et al. (Org.). O mundo rural no Brasil do século 21: A formação de um novo padrão agrário e agrícola. 1. ed. Brasília: Embrapa Informação Tecnológica, 2014. v. 1. 
BÚRIGO, F. L.; CAPEllesso, A. J.; CAZELlA, A. A. Evolução do Pronaf crédito no período 1996-2013: redimensionando o acesso pelos cadastros de pessoa física. In: CONGRESSO DA SOCIEDADE BRASILEIRA DE ECONOMIA, ADMINISTRAÇÃO E SOCIOLOGIA RURAL, 53., 26-29 jul. 2015, João Pessoa. Anais...Brasília: Sober, 2015. Disponível em: http://icongresso.itarget.com.br/tra/arquivos/ser.5/1/4326.pdf. Acesso em: 14 mar. 2016

CASTEL, R. La montée des incertitudes:travail, protections, statut de l'individu. Paris: Éditions du Seuil, La couleur des idées, 2009.

CAZELLA, A.A. multifuncionalidade agrícola: a defesa de subsídios públicos para o desenvolvimento rural.Marco Social, Rio de Janeiro, n. 7, p. 12-15, jul. 2007.

COHN, A. Cartas ao Presidente Lula: Bolsa Família e direitos sociais, Rio de Janeiro: Pensamento Brasileiro, 2012.

DELGADO, G. C. Capital financeiro e agricultura no Brasil: 1965-1985. São Paulo: Editora da Unicamp, 1985.

Previdência social e desenvolvimento rural. In: GRISA, C.; SCHNEIDER, S. (Org.).

Políticas públicas de desenvolvimento rural no Brasil. Porto Alegre: Editora da UFRGS, 2015.

; CARDOSO, J. C. (Org.). A universalizaçáo de direitos sociais no Brasil: a previdência rural nos anos 90. Brasília: IPEA, 2000.

FUNDO NACIONAL DE DESENVOLVIMENTO DA EDUCAÇÃO - FNDE. Centro Colaborador emAlimentação e Nutrição do Escolarde Santa Catarina.Histórico do maior programa de alimentação em atividade no Brasil. 2015. Disponível em: <http://www.rebrae. com.br/conteudo_noticia.php?id=5500\#.VS11-fnF-dE>. Acesso em: 14 mar. 2015.

GRISA, C.; SCHNEIDER, S. (Org.). Políticas públicas de desenvolvimento rural no Brasil. Porto Alegre: Ed. da UFRGS, 2015.

.; WESZ JUNIOR, V. J.; BUCHWEITZ, V. D. Revisitando o Pronaf: velhos questionamentos, novas interpretaçóes. Revista de Economia e Sociologia Rural, v. 52, n. 2, p. 323-345, abr./jun. 2014. Disponível em: <http://dx.doi.org/10.1590/S010320032014000200007 >. Acesso em: 10 out. 2014.

GUANZIROLI, C. E. (Coord.). Diretrizes de política agrária e desenvolvimento sustentável. Brasília: FAO/Incra, 1994. 
HAMEL, M.-P. WARIN, P. Non-recours (Non-take up). In: BOUSSAGUET, L.; JACQUOT, S.; RAVINET, P. (Org.). Dictionnaire des politiques publiques. 4. ed. Paris: Sciences Po Les Presses, 2014. p.383-390.

HESPANHOL, R. A. de M.Programa de Aquisição de Alimentos: limites e potencialidades de políticas de segurança alimentar para a agricultura familiar. Sociedade \& Natureza, v. 25, n. 3, p. 469-483, 2013. Disponível em: <http://www.scielo.br/scielo.php?script=sci_ arttext\&pid=S1982-45132013000300003\&lng=en\&nrm=iso >. Acesso em: 14 mar. 2015.

INSTITUTO BRASILEIRO DE GEOGRAFIA E ESTATÍSTICA - IBGE. Censo Agropecuário 2006: Manual do Recenseador. Rio de Janeiro: IBGE, 2007.

Censo Agropecuário 2006: Brasil, grandes macrorregiôes e unidades da Federação. Rio de Janeiro: IBGE, 2009.

INSTITUTO NACIONAL DE COLONIZAÇÃO E REFORMA AGRÁRIA - INCRA. Painel dos assentamentos. Brasília: Incra, 2015. Disponível em:<http://painel.incra.gov.br/ sistemas/index.php>. Acesso em: 31 maio 2015.

LAMARCHE, H. (Coord.). L'agriculture familiale: une réalité polymorphe. Paris: L'Harmattan, 1991.

MAIA, G. B. da S. et al. O Pronaf B e o financiamento agropecuário nos Territórios da Cidadania do Semiárido. Revista do BNDES, n. 37, p. 177-216, jul. 2012.

MARESCA, S. Les dirigeants paysans. Paris: Les Éditions de Minuit, 1983.295p.

MENEZES, F.; SANTARELLI, M. Da estratégia do"Fome Zero" ao Plano "Brasil Sem Miséria”: elementos da seguridade social no Brasil. Rio de Janeiro:Instituto Brasileiro de Análises Sociais e Econômicas,2013. Disponível em: <http://www.ibase.br/pt/wp-content/ uploads/2013/02/proj-fomezero.pdf>. Acesso em: 14 mar. 2015.

NIEDERLE, P. A.; FIALHO, M. A. V.; CONTERATO, M. A. A pesquisa sobre agricultura familiar no Brasil: aprendizagens, esquecimentos e novidades. Revista de Economia e Sociologia Rural, Piracicaba, v. 52, supl. 1, p. 9-24, 2014.

SCHNEIDER, S., MATTEI, L., CAZELLA, A. A.Histórico, caracterização e dinâmica recente do Pronaf - Programa Nacional de Fortalecimento da Agricultura Familiar. In: SCHNEIDER, S.; SILVA, M. K.; MARQUES, P. E. M. (Org.). Políticas públicas e participaçáo social no Brasil rural. Porto Alegre: Editora da UFRGS, 2004. p. 21-50.

SHANIN, T. La clase incómoda: sociología política del campesinato en una sociedad en desarrollo (Rusia 1910-1925). Oxford: Alianza Editorial, 1972. 
SOUZA, P. M.; PONCIANO, N. J.; NEY, M. G.; FORNAZIER, A.Análise da evolução do valor dos financiamentos do Pronaf-crédito (1999-2010): número, valor médio e localização geográfica dos contratos. Revista de Economia e Sociologia Rural, v. 51, n. 2, p. 237-254, 2013. Disponível em: <http://dx.doi.org/10.1590/S0103-20032013000200002>. Acesso em: 10 jun. 2013.

YUNUS, M.; JOLIS, A. E. O banqueiro dos pobres. São Paulo: Ática, 2000.

ZANI, F. B.; COSTA, F. L. da. Avaliação da implementação do Programa Nacional de Fortalecimento da Agricultura Familiar: novas perspectivas de análise. Revista de Administraçáo Pública, v. 48, n. 4, p. 889-912, 2014.

Recebido em: 19/04/2016.

Aceito em: 08/07/2016.

\section{Rural Development Policy in Brazil: the dilemma between productive inclusion and social}

\section{Abstract}

In the past two decades an evident dichotomy has been established between policies of a productive nature and those aimed at social assistance for family farms in Brazil. The purpose of this article is to analyze this duality in the main public policies for family farming, and presents a quantitative overview of the results. From a methodological perspective the analysis was based on the number of farmers who benefit from the agrarian reform policies, rural credit, institutional food markets, rural social security and income transfer. The main results of this study indicate that the economic support for the productive activities of Brazilian family farming have been concentrated among the intermediary and well-established farms that are inserted in markets. In parallel, most family farmers are relegated to social assistance programs and not integrated to the working agendas of the main professional organizations in agriculture.

Keywords: Family farming. Socio-productive inclusion. Non-take up. 